\title{
RISK MANAGEMENT IN THE EDUCATIONAL SECTOR OF LATVIA
}

\begin{abstract}
Vulnerabilities and risks in the educational sector affect policy makers, education providers and education receivers. Weak risk management increases the likelihood of misaligned priorities, poor service delivery and financial losses. Risk management is crucial part of effective management of education, provision of qualitative educational services and sufficient fair distribution of financing for higher education. However, in Latvia this topic is only starting to gain attention of regulators and managers in the educational sector.

The task of this research is to analyse existing worldwide research on risks and risk management practices within the educational sector. Upon the results of the research basic recommendations for risk management within the educational sector in Latvia will be drawn. The purpose is to provide a short introduction to risk management in the context of management of education.

This is a desktop study research involving analysis of published articles in academic databases, books, governmental publications, regulatory texts and public online resources.
\end{abstract}

Keywords: education, educational sector, risks, risk management, quality of education.

\section{Introduction}

The Institute of Risk Management (2002, p. 2) highlights that "Risk management is a central part of any organisation's strategic management." P. Tufano (2011) states that Risk management within any organization helps to identify and consider a combination of different types of events and its impact, thus giving any organization a chance to correctly analyse opportunities and treats for strategic planning. Clark, S. B., et al. (2013) and Adams, J. F. (1973) state that ensuring safe environment, effective 
and cost efficient curriculum provision through assessing and mitigating involved risks is the core responsibility of educational institutions.

Asian Development Bank ([ADB], 2010) sets out an overview of the risks to which the education sector globally is vulnerable, which are: lack of clearly defined processes and legal frameworks (e.g. in such important processes as admissions, recruitment, budgeting, procurement), misaligned priorities, bribery and corruption, weak financial management, poor internal culture, poor Information Systems, lack of relevant expertise on management level, poor security provision. Dunklee, D. R. and Shoop, R. J. (1993), in turn, analyse and discuss risks, mentioned in [ADB] (2010), related to personnel development programmes and their compensations, environment and safety management, disputes and litigations, usage of institution's facilities and grounds by the community and risks pertained to the construction of buildings. Forlin, P. (1995) confirms that the most undervalued risks are related to the educational environment, especially health and safety of employees and students. Clark, S. B., et al. (2016) further concludes that the interconnected risks are emerging, such as cyber, data management and privacy risks, terrorism and violence risks, infrastructure and facilities' management risks; and that a broader approach to risk management is required.

As concluded by the authors mentioned above, application of risk management techniques within the educational sector is important for quality improvement, transparency in educational institutions operations and effective decision making and strategic planning.

\section{Methodology}

The study was conducted by qualitative analysis of available theoretical material, including scientific research publications, non-scientific research articles, governmental reports, academic books and news websites, with the purpose to attract interest and raise awareness of education management professionals. The materials mainly were searched in electronic academic databases (EBSCO, ERIC, DOAJ), as well as in online news portals (News.lv, bbc.com, reuters.com), institutional websites (CERT.LV, mk.gov.lv, izm. gov.lv, dvi.gov.lv, knab.gov.lv) and by use of Internet search engine for additional information. The search words used in the electronic academic database catalogues were "risk management", "risk management in education", "risku vadība izglìtībā", "crisis management in schools", "cyber security in educational sector", "legal risks in education", "lawsuits in education", "fines and sanctions to education providers". Search words used in news portals were: "corruption in education sector", "corruption 
in schools", "violence in schools", "crisis management in education", "cyber security in education", "fines and sanctions to education providers", "korupcija izglīiības sektorā", "vardarbība skolās", "krīzes vadība izglīīīā", "kīiberdrošība Izglīîibas sektorā", "sodi un sankcijas izglītības iestādēm". All abovementioned search word combinations were used in Internet search engine for additional information.

All found articles and publications were analysed for definition of risk management by different authors, the risk management approaches, risk theories, examples and practical application of risk management techniques in the educational sector across the world.

\section{Results}

Risk management serves as the base for effective planning and strategic development for many organisations. However, it is often ignored in the educational sector. Following searches in EBSCO, ERIC and DOAJ databases, publications performed by Latvian researches about risks and risk management in education were not found at all. Within the Latvian University database of dissertations it was possible to find only one work titled as "Impact of Information Risk Management on Strategic Decision Making within the Business Management Context" by Schwerd, S. published in 2017. Following the search in library catalogues (Latvian University Library, Central Riga Library), it was not possible to find specific texts related to risk management within the management of education, instead some books found were related to the risk management in business and at the workplace. On the other hand, performing the same search for works written by foreign authors, it was possible to find a high number of books, publications and research projects conducted in the United States, Australia, Asian countries, United Kingdom, the Republic of Ireland, Sweden, Norway and Finland. Thus, it is possible to conclude, that there has not been performed any extensive research on this topic in Latvia, despite the worldwide accepted importance of risk management for any organisation in any sector.

Summing up the desktop research results, the author selected and analysed several risks, which were most often analysed in the researched materials and, therefore, may have the highest level of relevance to the educational sector: privacy and cyber security risks, risk of corruption, legal risks (compliance, litigation, lack of internal processes) and external risks (Tufano, P., 2011; Clark, S. B., et al., 2013; Adams, J. F., 1973; [ADB], 2010; Dunklee, D. R. and Shoop, R. J.,1993, Forlin, P., 1995; Abraham, J. M., Baird, R., Neugebauer, F., 2013). 


\section{Discussion}

\section{Cyber Security Risk in the Educational Sector}

According to the statistics provided by CERT.LV, solely during 2017 only in Latvia in total, were registered 477252 endangered by cyber attacks unique IP addresses.

According to Cyber Security Strategy of Latvia (2014) and Clark, S. B., et al. (2016), Cyber security risks are dangerous for educational sector from various angles:

1. Confidential data stored in educational institutions' and educational authorities' digital spaces may be at risk of being stolen, damaged or destroyed;

2. Digital devices used by educational institutions and authorities may be damaged by a virus and destroyed indefinitely causing severe financial damage.

According to the Cyber Security Strategy of Latvia (2014), there is lack of academic study programs and scientific activities in the field of cyber security in Latvia, and in the respective fields students studying abroad are not motivated to return to Latvia due to remuneration issues and lack of opportunities for professional development. Furthermore, according to latest statistics published the Ministry of Education (2018), in 2017 there was one programme dedicated to cyber security - Master in Cyber Security Management, provided by BA School of Business and Finance. Moreover, according to a study by the World Economic Forum, Latvia ranks only $110^{\text {th }}$ in terms of availability of scientists and engineers inside the country.

According to Cyber Security Strategy of Latvia (2014) in order to tackle cyber security risks, it is important to carry out educational and information campaigns for the promotion of public awareness for cybersecurity, cybercrime and existing threats. The author adds that it is crucial to encourage development and implementation of relevant specialisation programmes in higher education, include cyber security topics in the curriculum of secondary education and encourage practical application of cyber risk management techniques in the management of education (Clark, S. B., et al., 2013; Abraham, J. M., Baird, R., Neugebauer, F., 2013).

\section{Corruption Risk}

Risk of corruption mainly is driven by unethical behaviour of responsible employees and school administrators, which in turn could be limited by lack of well-defined procedures and regulations governing purchasing of supplies, use of common textbooks, hiring service providers etc. Corruption 
risk affects the quality of education, as well as safety and wellbeing of students and teachers. Bribes result in weakening of the quality of education, non-implementation of relevant procedures, assessment criteria and certification results (Chr. Michelsen Institute, 2006; Hallack and Poisson, 2007).

Upon analysing available research publications ([ADB, 2010; Chr. Michelsen Institute, 2006; Hallack and Poisson, 2007) and related news articles published in the Corruption Prevention and Combating Bureau of Latvia (KNAB.gov.lv), the State Police of Latvia website (vp.gov.lv) and local news websites (News.lv, tvnet.lv, delfi.lv), the following issues related to corruption risk were identified by the author:

- Absence or non-implementation of established processes and methods for reviewing teacher performance and teacher external engagements provides opportunities for corruption risk;

- Corruption may be the reason for reduced quantity of textbooks and low textbook quality;

- Deficient and unsafe materials may be used in school construction as a result of corruption;

- Corruption incidents may result in differing funding levels provided to similar educational institutions. Moreover, corruption incidents have resulted in more paperwork involved for schools applying for funding, in order to increase the controls over the corruption risk.

\section{Legal risks}

Educational sector often is subject to regulatory reforms and regulatory changes. In Latvia, education sector is not only the subject to local laws, but also to several common European Union (EU) laws. Education is strictly regulated and requires authorities and school administrators to closely follow changes legal requirements and stay compliant. Ensuring strong compliance would additionally foster better quality in provision of education (Abraham, J. M., Baird, R., Neugebauer, F., 2013; ADB, 2010; Chr. Michelsen Institute, 2006; Clark, S. B., et al., 2013; Hallack and Poisson, 2007).

One of such upcoming regulations, which will impact all educational institutions, is the EU General Data Protection Regulation (GDPR). This regulation requires each institution, especially public, which processes large amounts of personal data, to appoint Data Protection Officer. Moreover, apparently the impact on academic research will take place, as the data availability will become more complicated. The real outcomes and effect on educational sector of this regulation will become obvious only after the regulation will come in force. 
Finally, the educational reforms that happen regularly in Latvia may not always be in interests of all stakeholders, what creates further risks requiring additional research.

\section{External risks}

External risks may take form of flood, fire, terrorist attacks, nature disasters, failures in supply management, losing a key employee, sudden death of child or teacher, etc. Disruptions caused by external factors, occurrence of which is not possible to control, can happen at any moment. It is important to be prepared and ready to face the incident, with clearly planned actions and appointed beforehand responsible persons, to enable organizations to continue functioning with as little interruption as possible (PKF UK LLP, 2011; ADB, 2010; Lehtonen, J., Silina, R., Abelniece, B., 2011).

In Latvia, the Ministry of Education and Science has developed the Civil Protection Procedure (2011), the Children Rights Protection Inspection has published the Crisis Management Procedure for Schools (2015), but the Employer Confederation of Latvia published the Best Practice Management Handbook (2010). Further research is required, in order to assess, whether and to what extent these documents are utilised, which is not in scope of this publication.

\section{Conclusions}

Due to lack of sufficient information from authors and information sources of Latvia, it was challenging to analyse risk management and current risks in educational sector in Latvia. Therefore, author will continue to research this topic by applying other methods, such as interviews, empirical research, applied quantitative approach. To conclude on current research results, academic studies on risk management in educational sector of Latvia should be encouraged. Curriculum programs in higher education institutions related to risk management problems should be developed and regularly organised scientific conferences dedicated to risk management, where future risks and required expertise would be assessed. Existing worldwide research should be considered for addressing specific problems in Latvia and the up-to-date statistics should be available for researches.

Corruption risk related to school funding can be mitigated by a clear centralised sourcing and procurement policy for all educational institutions with embedded control techniques for and specific criteria set for choice of suppliers.

One of the steps to tackle cyber risks is to follow and develop the Cyber Security Strategy and to ensure that education in ICT cyber security is 
integrated it into the school curriculum. Systematic continuing education sessions should be organised for teachers on tackling security, privacy and cyber security issues, as well as trainings on actions that need to be taken in the events of unexpected disaster situations caused by the external factors.

\section{References}

Abraham, J. M., Baird, R., Neugebauer, F. (2013). Leveraging Enterprise Risk Management: Opportunity for Greater Relevance. EDUCAUSE Review, Nov.-Dec. 2013, 48(6), 28-40. ISSN-1527-6619. ERIC database.

Adams, J. F. (1973). The Governing Board's Role in Risk Management and Insurance for Higher Education. Journal NACUBO Professional File, Mar. 1973, 4(1). ERIC database.

Asian Development Bank (2010). Education sector risk assessment. Philippines: ADB. ISBN 978-92-9092-163-9. Retrieved from https://www.adb.org/sites/default/files/ institutional-document/31318/guidance-note-education-sector-risk-assessment.pdf.

Basel Committee of Banking Supervision (2011). Principles for the Sound Management of Operational Risk. Bank for International Settlements, June 2011. Retrieved from https://www.bis.org/publ/bcbs195.pdf.

CERT.LV (2018). Publiskais pārskats par CERT.LV uzdevumu izpildi 2017. gadā (Public report on fulfillment of CERT.LV tasks). Published on 23.03.2018 online on CERT.lv. Retrieved from https://cert.lv/uploads/CERT-LV_gada_2017_publ_galaversija.pdf.

Chassang, G. (2017). The impact of the EU general data protection regulation on scientific research. Ecancermedicalscience online journal, 11, 709. Retrieved from https:// www.ncbi.nlm.nih.gov/pmc/articles/PMC5243137/.

Chr. Michelsen Institute (2006). Corruption in the Education Sector, U4 Anti-Corruption Resource Center, Issue 4. Bergen, Norway: Chr. Michelsen Institute. Retrieved from https://www.cmi.no/publications/file/2563-corruption-in-the-education-sector.pdf,

Clark, S. B., DeCato, K. D., George, D., Henderson, D., Henry, A. A. Jr., Hoch, Ch. (2016). Enterprise Risk Management in the Great City Schools, Spring 2016. Washington D.C.: Council of the Great City Schools. ERIC database.

Dunklee, D. R., Shoop, R. J. (1993). A Primer for School Risk Management: Creating and Maintaining District and Site-Based Liability Prevention Programs. U.S.A.: Allyn and Bacon.

Forlin, P. (1995). Risk management in Australian science education: A model for practice. Australian Science Teachers Journal, June 1995, 41(2), 22-28. ISSN-0045-0855.

Hallak, J., Poisson, M. (2007). Corrupt Schools, Corrupt Universities: What Can be Done? UNESCO: Ethics and Corruption in Education. Paris: International Institute for Educational Planning. Retrieved from www.unesco.org/iiep.

HM Treasury (2004). The Orange Book: Management of Risk - Principles and Concepts. London: HMSO. Retrieved from www.hm-treasury.gov.uk/d/orange_book.pdf.

Institute of Risk Management (2002). The Risk Management Standard. London: IRM. Retrieved from https://www.theirm.org/media/886059/ARMS_2002_IRM.pdf.

Lehtonen, J., Silina, R., Abelniece, B. (2011). Riska un Krizes komunikācija (Risk and Crisis Communication). Latvia: Biznesa Augstskola Turība.

Martoglu, M. (2015). The Role of School Management in the Prevention of School Violence. Procedia - Social and Behavioral Sciences, 182 (2015), 695-702. Elsevier Ltd. Retrieved from https://doi.org/10.1016/j.sbspro.2015.04.815. 
Ministry of Defence of Latvia (2014). Latvijas kiberdrošǐbas stratēgija 2014-2018 (Cyber Security Strategy of Latvia 2014-2018). Retrieved from https://www.unodc.org/res/ cld/lessons-learned/lva/latvijas_kiberdrobas_stratija_html/Kiberdrosibas_strategija.pdf.

Ministry of Education and Science of Latvia (2018). Pārskats par Latvijas augstāko izglītibu 2017. gadā. Galvenie statistikas dati (Overview of Latvian Higher Education in 2017. Key Statistics). Retrieved from http://www.izm.gov.lv/images/izglitiba_augst/Parskats-parLatvijas-augstako-izglitibu-2017gada.pdf (2018-04-27).

Ministry of Education and Science of Latvia (2018). Studiju programmas 2017 (Study Programmes 2017). Retrieved from http://www.izm.gov.lv/images/statistika/augst_ izgl/Studiju_programmas_2017.xlsx (2018-04-27).

Murphy, K. L., Donovan, J. B., Berg, D. A. (2016). Analysis of Risk Management in Adapted Physical Education Textbooks. Physical Educator, Spring 2016, 73(2), 388-414. ISSN-0031-8981. Retrieved from http://dx.doi.org/10.18666/TPE-2017-V74-I1-6441.

Patrinos, H. A., Kagia, R. (2007). In The Many Faces of Corruption: Tracking Vulnerabilities at the Sector Level. Washington, DC: The World Bank. Retrieved from http:// documents.worldbank.org/curated/en/571831468315566390/The-many-faces-ofcorruption-tracking-vulnerabilities-at-the-sector-level

PKF UK LLP (2011). A Good Practice Guide To Risk Management Within The Further Education Sector. London: PKF (UK) LLP. Retrieved from https://www.aoc.co.uk/sites/ default/files/CFDG_Risk_Management_Guide_0.pdf. 